\title{
'NO ONE KNOWS ANYTHING': KINSHIP CAREGIVERS AND THEIR EXPERIENCES WITH SOCIAL SERVICES IN POLAND
}

\section{MICHALINA GRZELKA ${ }^{1} \&$ KATARZYNA SZOSTAKOWSKA ${ }^{2}$}

${ }^{1}$ State University of New York at Albany, Department of Anthropology, 1400 Washington Ave, Albany, NY 12222, United States. ORCID: 0000-0003-3753-8632, Email: mgrzelka@albany.edu

2 The Maria Grzegorzewska University, Szczesliwicka 40, 02-353 Warsaw, Poland. ORCID: 0000-00034113-434X, Email: kszostakowska@aps.edu.pl

ABSTRACT: This paper provides a window into the ways kinship caregivers of elderly persons and people with disabilities describe their experiences with social services in Poland. Kinship caregivers in Poland, the majority of whom are women, often struggle with inadequate access to social services dedicated to people with disabilities and the elderly. One of the major issues faced by caregivers who try to secure these services, are complex rules and regulations which frequently make it very difficult to access information and assistance. By the way of critical discourse analysis, this paper examines letters by and interviews with kinship caregivers in Poland. These two data sets present the problems faced by kinship caregivers of elderly persons and people with disabilities who are frequently left frustrated by their interactions with the social services system and its gatekeepers. Therefore, the authors hope that this study will provide policymakers responsible for social policy in Poland with some useful insights and suggestions.

KEYWORDS: aging, caregiving, disability, family, gender 


\section{INTRODUCTION}

The neoliberal reforms introduced in Poland after the collapse of state socialism in 1989 have resulted in the outsourcing of much of state's responsibility for providing care to children, people with disabilities, and the elderly to ordinary citizens, mostly women. Glass and Fodor (2007) argue that after 1989 policymakers in Poland have "pursued a form of 'private maternalism' in which the market and the family have become the primary institutions of welfare provision" (2007: 325). Nowadays, as a result of these neoliberalizing efforts, people with disabilities and elderly persons as well as their kinship caregivers have very limited access to assisted care, even though this type of support is recommended by European disability policies (Priestley 2007). Consequently, elderly people and people with disabilities who require daily assistance can usually only count either on their relatives (mostly mothers and daughters) or (rarely) nursing homes. Due to this lack of state support in the area of assisted care, about two million Poles act as caregivers for their elderly or disabled family members (Żebrowski 2019).

The question of who is responsible for providing care to those people with disabilities and elderly persons who require daily assistance remains one of the thorniest issues of Polish social policies. Therefore, the primary goal of this paper is to analyze, by the way of critical discourse analysis, the ways kinship caregivers of people with disabilities and elderly persons describe their experiences with social services in Poland. In order to achieve this, this paper asks the following questions: How do kinship caregivers rate their access to such vital information as applying for benefits among others? What are their experiences of dealing with the gatekeepers of the system, that is social workers and medical professionals among others? And, finally, how, in their opinion, social services available to people with disabilities, elderly persons and their kinship caregivers in Poland could be improved based on their lived experience? In addition, this paper will attempt to trace the effects caring for an elderly or disabled relative with little to no support from the state has on the wellbeing of caregivers.

\section{DATA AND METHODOLOGY}

This study will employ discourse analysis as a way of examining two data sets. The first data set consists of fourteen letters, editorials, and interviews that appeared in the online edition of Gazeta Wyborcza, one of the biggest Polish news outlets, and its affiliated portals in Spring 2018. We decided to look at these particular sources because they were published in the midst of two events that stirred a national debate on people with disabilities in Poland at that time. First, in March 2018 the conservative Life and Family Foundation announced their plan to ban abortion on the grounds of the irreversibly damaged fetus. Second, in April 2018 people with disabilities and their kinship caregivers began a forty-day occupation of the hall of the Polish parliament building demanding better benefits for people with disabilities and their caregivers. Hence, the majority of the sources in this data set were authored by or were written about people, mostly women, who act as kinship caregivers for their relatives, usually their children, with disabilities. 
The second data set consists of twenty transcribed interviews with kinship caregivers of elderly persons collected by one of us (Katarzyna Szostakowska) in 2015. She conducted these interviews as a part of her doctoral research with kinship caregivers of elderly persons in Torun, Poland. It has to be underscored that the data analyzed for the purpose of this study constitute just a small part of a larger research concerned with kinship caregivers of elderly persons in Poland. The analysis of the interviews was performed with the help of MAXQDA - a data analysis software used by researchers who collect qualitative data. Similarly to the sources from the first data set, the majority of the interviews collected in the second data set were conducted with women (eighteen out of twenty interviews), who were daughters, daughters-in-law, and wives of elderly persons who required their assistance. It has to be underscored that the sources in both data sets were originally provided in Polish and therefore some of them were later translated to English for the purpose of this study.

In order to answer our research questions, we will analyze both data sets by utilizing critical discourse analysis (CDA) defined by Baker and McEnery (2014) as "a way of doing discourse analysis from a critical perspective, which often focuses on the theoretical concepts such as power, ideology, and domination" (2014: 465). This implies that the analysis of linguistic features of secondary data cannot be conducted without an analysis of wider social context, which, in this case, are laws and regulations regarding the question of caregiving for people with disabilities and elderly persons as well as gender roles associated with certain types of labor such as caring.

\section{CAREGIVING AS A GENDERED ISSUE}

Across cultures, caring for children, people with disabilities, and elderly people is often considered women's work. Discussing this gendered division of care, Stacey (2011) argues that "the social organization of care is an outgrowth of the emotional and occupational sexual division of labor" (2011: 6). Poland is no exception in this regard. In the 1990s the postsocialist government of Poland engaged in the "re-reforming" of their citizens who were now expected to act as "individuals... 'actively' responsible for their own lives and the welfare of their families” (Gal and Kligman 2000:74). However, as Gal and Kligman accurately point out, the withdrawal of subsidies as a way of relieving state budgets meant that it was women, not abstract "individuals" and "families", who "[took] up even more of the slack in sick care, elder care, and child care" (2000:74). Much of this work remains grossly undervalued, a consequence of socialist definitions of household work performed by women as lacking value, in contrast to wage work associated with men (Gal and Kligman 2000). For example, as a result of the systematic devaluation of women's labor that persisted long after the collapse of state socialism, Polish caregivers of family members with disabilities not only receive a very small allowance for their work, but they also cannot take any extra jobs that could improve their and their family members' financial standing without risking their meager state allowance (Jabłonowska 2017; Klukowska 2017). In Poland, mothers are responsible for the majority of care provided to people with disabilities (Sekułowicz 1998). Mothers are the ones who usually have to give up their careers in order to take care 
of their disabled children, since many fathers have trouble with coming to terms with the birth of a disabled baby (Sekułowicz 1998). Many of them abandon their families. For instance, in the 1990s the rate of students in "special" schools who did not live with both their parents was higher than average (Sekułowicz 1998). Sekułowicz (1998) argues that the stereotype of women solely responsible for caring for and raising children is particularly strong in Poland.

In Poland, women are also responsible for the majority of caregiving required by elderly persons who need assistance with their day-to-day activities. This assistance is usually provided by elderly persons' daughters or daughters-in-law who, at the same time, not only care for their aging parents, but often are also responsible for supporting their own children. Therefore, these daughters constitute what is referred to by some researchers as sandwich generation (Szatur-Jaworska, Błędowski, and Dzięgielewska 2006). However, it has to be underlined that women increasingly refuse to act as main caregivers to their aging parents, parents-in-law, and other family members requiring daily assistance (Giddens 2012). This may be caused by the strenuous and demanding, both physically and mentally, labor which constitutes a major part of the act of caregiving. Some researchers argue that due to the multitude of their duties kinship caregivers are often afflicted with the Sisyphus syndrome meaning that they eventually become burned-out as a result of fatigue and stress (Grochmal-Bach 2007). Ultimately, as a consequence of women's changing attitudes toward caregiving as well as their increasing awareness of difficulties and risks associated with providing care, the responsibility for caring is sometimes outsourced to paid professionals (Giddens 2012), however it has to be underscored that not every family can afford this type of external support (Zięba-Kołodziej 2014).

\section{REGULATIONS}

\section{Assisted care and people with disabilities}

Some researchers argue that since the collapse of state socialism in Poland, the country has been overly focused on economic issues, while ignoring social problems, which has ultimately led to the lack of coherent social public policy (Woźniak 2008). Similarly to Mladenov (2017), who points out that after 1989 formerly socialist countries of Central and Eastern Europe followed the path of neoliberalization of their social policies, Woźniak (2008) argues that the new social policy developed in Poland after the collapse of the socialist regime was largely focused on partial dismantling of laws introduced under state socialism. New authorities, however, failed to replace the old "socialist" approaches toward social issues with new legislation that would form the basis of consistent social policy (Woźniak 2008).

This lack of coherent social policy creates confusion for people with disabilities in Poland, as well as their caregivers. The question of who is responsible for providing care to those people with disabilities who require daily assistance remains one of the thorniest issues of Polish disability policy. For instance, the Charter of the Rights of Persons with Disabilities adopted in 1997, which is the most important legislation regarding people with disabilities in Poland, does not address the question of caregiving 
at all. The Charter, which contains four paragraphs and is less than two pages long, declares that people with disabilities have the right to an "independent and active life" and that they cannot be discriminated against (Karta 1997). It further specifies that people with disabilities have the rights to medical care, education, psychological support, employment and accessible environment and public spaces among others (Karta 1997). It does not define, however, how exactly these rights are to be executed. Even though the Charter begins with the statement that people with disabilities have the right to independent living, it ignores the question of how people with disabilities who require care and assistance on a daily basis are expected to access this right. For example, even though the position of aide for people with disabilities ("asystent osoby niepełnosprawnej”) was first officially recognized by the Ministry of National Education in 2001, and regulated in 2004, Polish disability rights activists argue that the access to this type of service is still very limited (Próchniewicz 2015). In addition, there are several limits as to who qualifies for the support of an aide. First, state-covered aides can be provided only if the household income does not exceed PLN 524 (USD 138) per person (Próchniewicz 2015). Second, for instance in Warsaw, a person requesting the support of a personal aide needs to be over eighteen years old and in possession of either a disability certificate stating that their disability level is either significant or moderate (which means that people with the mild disability level are not eligible for these services) or belong to the first or second "invalid group", or be certified as a person who has lost their capacity to work (Asystent 2013).

Even though since 2004 Poland has been a member state of the European Union, which requires its member states to provide people with disabilities with assistant care (Próchniewicz 2015), the country continues to lag behind the older members of the European Union. Poland entered the European Union at the time when disability policies were high on the agenda of the European Union and new binding conditions of membership had been introduced in terms of "nondiscrimination and structural adjustment towards disability equality" (Priestley 2007:69). Despite these slogans, the harmonization of disability policy within the European Union is hampered by differing social, political, and economic circumstances of its member states. Poland is an example of a member state which, in comparison with the older European Union members such as Germany, Sweden or Denmark among others, has limited economic resources that can be devoted to the task of implementing the objectives of European disability policy (Priestley 2007). Some researchers admit that "the combination of subsidiarity and EU enlargement means that the pursuit of a hard policy approach to disability... is not easily implemented through EU institutions" (Priestley 2007:70).

\section{Social services and the elderly}

In Poland, there exists a system of providing care and assistance to elderly persons. This system encompasses various forms of activities, whose main goal is to increase elderly people's participation in the social life of their communities as well as to enhance their physical and mental health. These various forms of public support are managed and administered by Family Support Centers (Ośrodki Pomocy Rodzinie 
- OPR) and Municipal Social Support Centers (Miejskie Ośrodki Pomocy Rodzinie MOPR) among others. According to the Social Welfare Act elderly persons (as well as people with disabilities) are also eligible for such forms of public support as cash benefits, material support, and assisted care among others (Pikuła 2011). In case these forms of support are not sufficient, an elderly person can apply for a placement at such institutions as day centers, nursing homes, and hospices (Zych 2010). However, it has to be underscored that such institutions are not always available to those who are eligible for this type of support, since the demand for those services exceeds the capacity of the institutions. In case an elderly person cannot secure a place at a nursing home or when a family is reluctant to place their elderly relative at an institution, one of the family members (usually a female one) can become her/his kinship/informal caregiver defined by Savage and Carvill as "someone who is unpaid and provides ongoing and regular assistance and support (physical or emotional) for a person with a physical and/or intellectual disability, mental illness or is frail aged" (2009: 87).

\section{GATEKEEPERS AND ACCESS TO INFORMATION AND SERVICES}

\section{"Bureaucratic conundrum"}

Nie ma takiego miejsca, żebyśmy poszli i ktoś nam przedstawi procedurę, nie ma takiego człowieka. Bo mąż dzwoni do MOPR-u (Miejski Ośrodek Pomocy Rodzinie - K.Sz.), pani mu powiedziała coś, potem ja poszłam i ona coś innego powiedziała. Dała papiery. Potem powiedziała, że czegoś brakuje. A ona do nas: poradźcie sobie (...). Tak więc my mamy sobie wszystko załatwić i jeszcze domyśleć się, co ta pani chce z MOPR-u. Od pani z MOPR-u dostaliśmy jedno ze wskazań między innymi do domu opieki na Podgórzu (dzielnica Torunia - K.Sz.). Po prostu trafiamy na matnię urzędniczą w postaci MOPR-u, gdzie pani posiada wiedzę zupełną i my nie jesteśmy w stanie się przez nią przebić bo ona nie jest zainteresowana udzieleniem informacji, pomocą. Tylko na zasadzie, że wy musicie spełnić warunki, a jak nie to trudno, to zaczynacie od nowa. No ale, kurde ja nie będę prawa administracyjnego studiowała (...) [Opiekun 19].

[There's no such place where we could go and learn about the procedure, there's no such person. Husband called MOPR [Municipal Family Support Center] and the lady [who worked there] told him one thing, then I went there and she told me something else. She gave [us] the paperwork. Then she said that something was missing. And she told us: deal with it. So we have to take care of everything on our own and try to figure out what that lady from MOPR wants from us. From the lady at MOPR we got a direction to a nursing home in Podgórze [a neighborhood in Toruń. We're simply faced with that bureaucratic conundrum in the form of MOPR, where the lady has all the knowledge and we're not capable of getting through her because she's not interested in sharing that knowledge, helping us. You have to fulfill the requirements, and if you don't, then hard luck, you have to start from scratch. But, damn, I won't go and study administration 
law (Caregiver 19)].

The excerpt above is a fragment of one of the interviews conducted with caregivers of elderly family members in Torun in 2015. In this piece, a family member describes her experience of trying to access vital information pertaining to a nursing home placement in Torun. In the excerpt, the caregiver underscores the difficulties she faced while trying to interact with a social worker from her local Municipal Family Support Center. Her narrative shows that according to her experience social workers can be indifferent in the face of the difficulties and challenges caregivers of the elderly struggle with. By referring to the way of accessing information and services as "bureaucratic conundrum" ("urzędnicza matnia") the caregiver underlines the difficulty of communicating with those social workers who are responsible for placing an elderly person in a nursing home. The word "damn" ("kurde") seems to underline the frustration with the system, whereas the comment about having to study administration law in order to comprehend various rules and regulations highlights the complexity of obtaining and understanding the information crucial for securing a placement at a nursing home for her elderly relative.

\section{“No one knows anything"}

Nikt nic nie wie. Nie wie, gdzie cię kierować. Jak już mniej więcej trafisz na dobry kierunek, okazuje się, że terminy są w przyszłym roku. Liczba godzin terapii dla dziecka jest śmieszna (...), musisz wywrócić Internet do góry nogami, żeby dołożyć liczbę godzin wczesnego wspomagania za własne pieniądze (...). A jeśli ktoś mieszka w małym mieście, na wsi, nie ma samochodu i jest samotną matką, to jej życie i życie tego dziecka się skończyło. [Anonim 2018]

[No one knows anything. No one knows where to direct you. And if you finally find the right direction, it turns out that the next available date is next year. The number of therapy hours for a child is ridiculous, you have to comb through the Internet to find more early therapy hours and pay for them out of pocket. And if someone lives in a small town or in a rural area, doesn't have a car and is a single mother, then her life and the life of her child is over (Anonymous 2018)].

This is an excerpt from a Facebook post by a mother of a child with a disability, which was reprinted and discussed in an editorial that appeared in March 2018 on eDziecko.pl, a portal affiliated with Gazeta Wyborcza. Similarly to the excerpt above, the author expresses her frustration with the system in which "no one knows anything". She, too, feels trapped in the "bureaucratic conundrum" when trying to access services for her disabled child. In addition, the author acknowledges that there are certain groups of people in Poland, for instance single mothers and those who live in small towns, who are particularly vulnerable to the lack of state support. In order to highlight the difficulties faced by these demographics, she states that if you are a single mother of a child with a disability, then your life and the life of your child are over. 


\section{CAREGIVERS’ WELLBEING}

"I'm on my own"

Boję się (...), tak jakoś to już psychicznie ja chyba z tym sobie nie radzę, nawet nieraz to się wkurzę, przyjdę do Anny (sąsiadka - K.Sz.) i tak gadamy sobie. To już jest za długo i jestem sama. Bo gdybym tak ktoś wziął, na miesiąc, ja bym odpoczęła, trochę się zrelaksowała, czy nawet samą tą pracę miała już bez tej osoby, to może byłoby mi tak jak po urlopie, takim wiesz, jak byłam we Włoszech dwa tygodnie, ja naprawdę odpoczęłam wtedy [Opiekun 3].

[I'm scared, I think that mentally I can't deal with it anymore, sometimes I even get angry, and then I go to Anna [a neighbor - K. Sz.] and we talk. It's been too long and I'm on my own. Because, if someone took [her] for a month, I could rest, I could relax a bit, and maybe even if I only had my job without [having to care] for that person, then maybe I would feel like I'm on vacation, you know, like when I spent two weeks in Italy, I really rested then (Caregiver 3)].

In this excerpt, the interviewee discusses the effects the longtime labor of caring for an aging relative has had on her wellbeing. At the time of the interview, the woman had been taking care of her aging mother for thirteen years already. As discussed above, kinship caregivers often experience the burnout syndrome caused by the lack of support. The burnout syndrome makes caring for an aging relative even more difficult and challenging, since kinship caregivers, who oftentimes do not receive any support not only from the state, but also from other family members, experience low energy, depression and feel stuck in a situation with no easy way out. However, kinship caregivers frequently neglect their physical and mental health. The interviewee seems to display the signs of the burnout syndrome, but she cannot take time off in order to take care of her own needs. When she says: "I think that mentally I can't deal with it anymore" ("tak jakoś to już psychicznie ja już chyba z tym sobie nie radzę") she expresses how tired she already is with the entire situation in which she acts as the sole caregiver of her mother. The interviewee feels like she has to deal alone with all the problems life throws at her. She points out that the possibility of sharing her concerns with the neighbor provides her with a necessary mental respite. At the same time, the interviewee is aware that she needs to rest. She would like to find someone who would take care of her mother for a month, so she herself could finally get some rest. However, those who promised her to help, left her alone with her problems.

\section{"I need to be here everyday"}

Nagle mój ojciec zachorował na ciężką chorobę. Zmarł bardzo szybko i w ciągu dwóch tygodni musiałam rzucić pracę, wyprowadzić się z miasta, zająć (...) wszystkim, co zostawił. I siostrą. Mama była załamana. Wróciłam do domu, a z moich marzeń nie zostało nic. Stałam się szoferem, psychologiem, organizatorem i reprezentantem spraw mojej siostry (...). Ostatnio zgłosiła się do mnie 
firma. (...) dostałam pracę, o której tak marzyłam (...). Odmówiłam, bo wymogiem byłby powrót do miasta. Kto zająłby się mamą i siostrą? Jak miałabym im spojrzeć w oczy? Pomoc raz na jakiś czas to za mało. Muszę być tu codziennie (Ewa 2018).

[Suddenly my father got very sick. He quickly died and within two weeks I had to give up my job, move from the city, take care of everything he had left. And [take care of] my sister. Mom was devastated. I returned home and nothing was left of my memories. I became a driver, a psychologist, an organizer and my sister's representative. Recently I got a call from a company. I got a job offer which I had dreamt about for so long. I refused because I would need to return to the city. Who would take care of mom and sister? How could I look them in the eyes? Helping once in a while is not enough. I need to be here everyday (Ewa 2018)].

This is an excerpt from a letter that appeared in the online edition of Gazeta Wyborcza in March 2018. The author had to give up her career and return home in order to help caring for her disabled sister. Similarly to the interviewee (Caregiver 3) from the excerpt above, the author feels like she is trapped in the situation with no easy way out. Even though she dreams about returning to the city and starting a new job, she is aware that without her daily assistance her mother and sister would have to make do without „a driver, a psychologist, an organizer”. At the same time, it seems that it is not just the sense of duty that keeps the author with her mother and sister, but also potential guilt. When she comments on the reasons for turning down the job offer, she claims that she would not be able to look her mother and sister in the eyes.

This excerpt shows the effects „private maternalism” (Glass and Fodor 2007) has had on people with disabilities and their families in Poland. As a result of the lack of state support, it is not only parents (mostly mothers), who are responsible for providing daily care to people with disabilities, but, in some cases, also their siblings. However, kinship caregivers of people with disabilities are becoming more vocal about their needs and struggles. Karolina Hamerska, a Polish disability activist and a Paralympic athlete, points out that until recently, disability had been considered a private matter in Poland, confined to the realm of one's home and family. She says that "a child with a disability was born and since that moment everything has happened in the private sphere" (Kowalska 2018:81). This notion was challenged in April 2018, when people with disabilities and their parents and caregivers began a forty-day occupation of the hall of the Polish parliament. By bringing with them to the parliament building, which is considered a public space, such personal items as mattresses, pillows and bed linen among others, and making public and visible the presence of people who are expected to stay at home, they crossed the line between the public and the private (Lipko-Konieczna 2018). They also made visible the labor of their kinship caregivers, usually their mothers, in the everyday practice of care. To sum up, the protests and the letters like the one discussed above are a proof that the attitudes toward the level of support the state should provide to people with disabilities and their families in Poland are slowly changing. 


\section{HOW TO IMPROVE THE SYSTEM?}

“Our regulations suck"

Politycy powinni dać dużo większe pieniądze opiekunom (...), bo nikt nie będzie chciał. To moje pokolenie to jeszcze, jak ja i Anna (sąsiadka badanej - K.Sz.), ale to młodsze jak usłyszy za jaką kwotę ma iść opiekować się swoją matką lub ojcem to myślisz, że pójdzie? Nie pójdzie, i będą musieli, ja odnoszę takie wrażenie, po doświadczeniach swoich w domu, po doświadczeniach w pracy, że muszą budować dużo więcej domów opieki, ale i muszą się zastanowić nad wynagrodzeniem bo w domu nie będą chcieli trzymać dzieci, wnuki takich osób, bo to są strasznie śmieszne pieniądze dla tych opiekunów (...). Te przepisy nasze są ciulowe, dobrze, że w tym sejmie trochę ruszyli (...), ja nie wiem, czy któryś z nich w ogóle się opiekował matką, czy jakimś ojcem, czy oni tam zdają sobie sprawę, a jak mają chorą matkę czy ojca to na pewno zajmują się obce osoby ale nie oni bo nie wierzę w to, że ktoś z rodziny to robi [Opiekun 3].

[Politicians should give caregivers more money, because otherwise no one will want [to be a caregiver]. [People of] my generation, like me and Anna [the interviewee's neighbor], are more likely [to be caregivers], but if the younger ones hear how much money they can get for caring for their mother or father, do you think they will do it? They won't, and they will have, I think after what I experienced at my own home, to build more nursing homes, but they also have to consider the allowance [for caregivers] because otherwise children, grandchildren of those people won't keep them at home, because caregivers receive some ridiculous allowances. Our regulations suck. Good that they finally took up some initiative at the Parliament, I don't know if any of them [members of the Parliament] has ever had to care for a mother or a father, if they are aware of anything, and if their mother or father are sick then for sure some strangers care for them, but not them [politicians], because I don't believe that any of their relatives actually does that (Caregiver 3)].

In this excerpt, the interviewee, who acts as a caregiver of her elderly mother, discusses one of the thorniest issues of the Polish caregiving system, that is inadequate financial resources. In Poland, caregivers of elderly persons usually struggle with financial problems. The interviewee, who cares for her mother with diabetes, points out that due to inadequate financial support received by caregivers from the state, the younger generation, in her opinion, will be less likely to give up their careers in order to act as poorly paid caregivers of their aging parents. According to the legislation issued by the Council of Ministers on July 31, 2018, persons who give up their careers in order to care for their aging parents can receive 620.00 złotych per month (Dz.U. 2018 poz. 1497) which translates to about \$155.00. In order to express her opinion on the amount of money paid to kinship caregivers of the elderly, the woman calls the benefit "ridiculous" ("śmieszny"), since she is aware that this amount does not allow caregivers and their aging relatives to meet many of their needs such as buying 
medications or paying for physical therapy. Therefore, many caregivers decide against giving up their careers to care for their aging relatives and as a result they have to tap into their own financial resources in order to pay for caregiving services provided by professional home aides.

Moreover, the woman points out that members of the Parliament are not aware of the difficulties faced by caregivers of the elderly. She is certain that they themselves do not need to perform caregiving labor and suggests that politicians have enough money to pay for external caregiving services and therefore they lack understanding and empathy when it comes to caregivers of elderly persons. The woman therefore believes that the amount of money paid to caregivers of elderly persons is so low because politicians, due to the lack of their own experience in this area, do not understand the challenges kinship caregivers of the elderly struggle with on a daily basis. Furthermore, in order to underscore the inadequacy of currently existing regulations concerned with kinship caregivers of the elderly, the interviewee points out that they simply "suck" ("są ciulowe”), which further underlines her frustration with the currently existing laws.

In her research conducted with home care aides in the United States, Stacey (2011) identifies "caring trajectories" of home care aides which usually begin with an unpaid care in their own home, taking care of their family members in an informal manner. Following that trajectory, some of those "informal" caregivers transfer to low-wage care work, which demonstrates "an important link between division of labor in the home and the labor market” (Stacey 2011:7). Pursuing the caring trajectory, according to which a person, usually a woman, transfers from an informal caring job at home to low-wage care work, Stacey (2011), adopting the term coined by Arlie Hochschild, refers to work performed by home care aides as "marketized private life" in which the lines between work and family space are blurred (9). However, it seems that in Poland caring trajectories are inverted. Kinship caregivers, usually women, have to give up their careers in other fields in order to perform low-wage care work on behalf of aging or disabled relatives. In this excerpt the interviewee points out that, unlike the previous generations, young people may be more hesitant to give up their careers to become full-time kinship caregivers due to financial concerns.

\section{“Society is getting older"}

U nas nie ma dużo domów pomocy społecznej a społeczeństwo się niestety starzeje a młodzi ludzie muszą niestety pracować (...). Ja bym chciała bardzo chętnie też pójść do pracy między ludzi, brakuje mi tego. (...) Nawet kiedyś z koleżanką się zmówiłyśmy i stwierdziłyśmy, że to nasze pokolenie jeszcze nie jest przyzwyczajone, że starsze osoby oddaje się gdzieś do domu opieki. Nie jesteśmy jakoś tak wychowani. (...) W Polsce nie ma rozpowszechnionego systemu opieki nad ludźmi starymi, to dopiero zaczyna się rozwijać [Opiekun 7]. 
[There aren't many nursing homes here and society is, unfortunately, getting older while young people, unfortunately, have to work. I really would like to go to work, among people, I miss that. Once I talked to a friend and we figured out that our generation isn't used to giving the elderly away to some nursing home. This is not how we were raised. In Poland there is no wide caregiving system for elderly people, it's just beginning to develop (Caregiver 7)].

In this excerpt, the interviewee observes that while Polish society is getting older, there is no coherent and nation-wide system of caring for elderly people in place. She points out that there exist certain stereotypes that may hamper the development of such a system. The woman theorizes that the lack of nursing homes in Poland may be caused by the fact that placing the elderly under institutionalized care is considered by society at large as inappropriate. In Poland, traditionally, the responsibility for caregiving for either the elderly or people with disabilities, is outsourced to their families with little to no state support. Institutional care is often perceived as being equal to abandoning or even getting rid of elderly or disabled relatives. However, the interviewee notes that there exists a generational difference in how people perceive institutional care. She claims that her generation was raised in a way that does not allow them to place their aging parents or other relatives at nursing homes. On the other hand, she recognizes that placing a relative in a nursing home is not necessarily an easy decision to make, since „young people have to work” („a młodzi ludzie muszą pracować”) and therefore sometimes they may be forced to „abandon” their elderly or disabled relatives due to their life circumstances. At the same time, she admits that building more nursing homes would help to alleviate this dilemma.

It has to be underscored, however, that due to the lack of personnel, residents of nursing homes frequently experience inappropriate care and treatment. Oftentimes, their individual needs are not taken under consideration by the overwhelmed personnel (Szarota 2004). This resonates with the research conducted by Nancy Foner with aides working at a nursing home in New York City. Foner (1995) points out that "nursing homes are institutions that aim, in a sense, to bureaucratize or rationalize affective care" (p. 53) with aides having to adhere to strict rules and schedules. Unlike home care aides, the aides studied by Foner hardly ever stay after hours in order to perform what Stacey (2011), who studied home care aides, acutely calls "surplus care" (2011: 79). Foner (1995) observes that "the nature of the nursing home environment makes it hard even for devoted workers to consistently offer sympathetic care" (1995: 2 ). Those aides who tend to be harsh or sometimes even brutal toward their clients are often awarded for their efficiency, whereas those who are attentive and gentle end up being punished for not adhering to the strict rules governing the nursing home (Foner 1995). That is not to say that the aides studied by Foner are in their majority insensitive and cruel: many of them respect their patients and care about them. The problem is that due to the "tyranny of regulations" (Foner 1995:58) in nursing homes, aides are encouraged to do their tasks quickly and efficiently instead of spending too much time on "emotional work" with clients. This rationalization of "affective care" can be observed in Polish nursing homes as well. It is reported that residents of nursing homes 
often experience the sense of isolation and alienation. Moreover, nursing homes are frequently crowded which can lead to the lack of privacy, conflicts between residents and personnel, as well as to loneliness and inadequate sense of safety (Mielczarek 2010).

\section{CONCLUSION}

\section{"The minimum subsistence level"}

(...) zawitaliśmy więc do opieki społecznej. Dowiedzieliśmy się, że pomoc nam nie przysługuje, bo zarabiamy powyżej ustalonego minimum socjalnego. A pomoc niematerialna? Odciążenie od opieki choć na kilka godzin? Nie - bo stać nas na opiekunkę. Zapewnienie Oli dodatkowych zajęć, warsztatów - nie, bo jest za bardzo "uszkodzona” (...). Ostatnio zapytaliśmy w DPS w Sopocie o możliwość zaklepania miejsca dla Oli w nowym domu pomocy społecznej w Sopocie (...). Niestety (...), [d]om jest przewidziany dla osób starszych i z chorobami nieuleczalnymi. Nigdy nie będzie dedykowany Oli. Dlaczego? Od kiedy Ola będzie uważana za osobę starszą i schorowaną? Dostaliśmy informację, że pewnie gdzieś na południu Polski znajdzie się dom. Wykaz na stronie internetowej takiej i takiej (Lewandowska 2018).

[So we went to the social welfare (center). We learned that we aren't eligible for any support, because we earn more than the minimum subsistence level. What about some other type of support, like respite care for a few hours? No - because we can afford a home care aide. Signing Ola up for some extra classes or workshops? No - because she's too "damaged". Recently we asked a nursing home in Sopot [a city in northern Poland - M. G.] if we could secure a place for Ola in a new nursing home in Sopot. Unfortunately, the home is dedicated to terminally ill and elderly people. It will never be dedicated to Ola. Why? When will Ola be considered old and sick? We were told that probably somewhere in southern Poland we could find a [nursing] home. The list is available on the website so and so (Lewandowska 2018)].

We decided to conclude our paper with the excerpt from a letter that appeared in the online edition of Gazeta Wyborcza in 2018. We believe that this fragment is reflective of many problems faced by kinship caregivers and discussed in this study. The letter was authored by mother of a seventeen years old girl named Ola who was born with a disability. First, the fragment presents the lack of understanding and empathy experienced by both kinship caregivers of elderly persons and people with disabilities when interacting with gatekeepers of the system such as social workers. For example, Ola is refused additional classes and workshops because she is considered too "damaged" as if she was an object and not a living person. Second, similarly to other excerpts discussed in this paper, the fragment cited above highlights the difficulties experienced by kinship caregivers when trying to access information about benefits and nursing homes. Since "no one knows anything", Ola's family is sent to the Internet in 
order to find a nursing home for her instead of being provided with assistance of social workers. Finally, the family cannot access respite care because they make too much money, the regulation which is reflective of the larger "bureaucratic conundrum" in which people who do not fit within narrow brackets of financial requirements are left to fend for themselves.

This paper provides a window into the challenges faced by kinship caregivers of elderly persons and people with disabilities in Poland. As a result of the conundrum of insufficient state support and societal expectations toward women, kinship caregivers and their elderly and disabled relatives occupy a uniquely precarious position within society. In order to change this situation, the state needs to start listening to their opinions on how social services in Poland frequently fail them and their family members and how, instead of support and advice, they are often met with indifference and lack of understanding.

FUNDING: This research received no external funding.

CONFLICT OF INTEREST: The authors declare no conflict of interest.

\section{REFERENCES}

Anonymous. 2018. "Mama nieuleczalnie chorego Mikołaja o zakazie aborcji: tu chodzi o szacunek do życia. Mojego.” [Mom of terminally ill Mikołaj on abortion: it is about respecting life. My life]. Gazeta Wyborcza, March 26. Retrieved November 9, 2018 (http://www.edziecko.pl/rodzice/7,79318,23192328,mama-nieuleczalnie-chorego-mikolaja-o-zakazie-aborcji-tu-chodzi.html).

Asystent Osoby Niepełnosprawnej. 2013. Warunki realizacji usług [Conditions of service delivery]. Asystent Osoby Niepełnosprawnej website, July 6. Retrieved March 18, 2019 (http://www.asystent.warszawa.pl/index.php/jak-sie-zglosic/ warunki-realizacji-uslug).

Baker, Paul, and Tony McEnery. 2014. “'Find the Doctors of Death.' Press Representations of Foreign Doctors Working in the NHS, a Corpus Based Approach.” Pp. 465-480 in The Discourse Reader, 3rd edited by A. Jaworski and N. Coupland. London \& New York: Routledge.

Dz.U. 2018 poz. 1497. ISAP. Retrieved October 8, 2018 (http://prawo.sejm.gov.pl/isap. nsf/DocDetails.xsp?id=WDU20180001497).

Ewa. 2018. „W spadku’ dostałam niepełnosprawną siostrę. Zrobię wszystko, aby urodzić zdrowe dzieci" [I "inherited” a disabled sister. I will do anything to have healthy children]. Gazeta Wyborcza, March 26, 2018. Retrieved November 9, 2018 (http://www.edziecko.pl/rodzice/7,163271,23220207,kosciol-nigdy-nie-zainteresowal-siesytuacjaniepelnosprawnych.html).

Foner, Nancy. 1995. The Caregiving Dilemma. Work in an American Nursing Home. Berkeley, CA: University of California Press.

Gal, Susan and Gail Kligman. 2000. The Politics of Gender after Socialism. Princeton, NJ: Princeton University Press. 
Giddens, Anthony. 2012. Socjologia [Sociology]. Warszawa: Wydawnictwo Naukowe PWN.

Glass, Christy, and Eva Fodor. 2007. "From Public to Private Maternalism? Gender and Welfare in Poland and Hungary after 1989.” Social Politics: International Studies in Gender, State and Society 14(3):323-350.

Grochmal-Bach, Bożena. 2007. Cierpienie osób z otępieniem typu Alzheimera: podejście terapeutyczne [Suffering of people with Alzheimer dementia: a therapeutic approach]. Cracow: Wyższa Szkoła Filozoficzno-Pedagogiczna „Ignatianum”.

Jabłonowska, Kamila. 2017. "To skandal, że kobieta zamykana w domu z niepełnosprawnym dzieckiem nie może dorobić" [It's an outrage that a woman locked at home with a disabled child can't make extra money]. Elbląski Dziennik Internetowy, September 20. Retrieved March 16, 2018 (https://www.info.elblag.pl/31,51580,To-skandal-ze-kobieta-zamykana-w-domu-z-niepelnosprawnym-dzieckiem-nie-moze-dorobic.html).

Karta Praw Osób Niepełnosprawnych [Charter of the Rights of Persons with Disabilities]. 1997. Monitor Polski 50:970-971. Retrieved March 19, 2019 (http://prawo. sejm.gov.pl/isap.nsf/download.xsp/WMP19970500475/O/M19970475.pdf).

Klukowska, Katarzyna. 2017. "Zasiłki dla opiekunów osób niepełnosprawnych” [Benefits for caregivers of disabled people]. Gazeta Wyborcza, November 29. Retrieved February 26, 2018 (http://wyborcza.biz/biznes/7,147582,22712009,zasilki-dla-opiekunow-osob-niepelnosprawnych.html?disableRedirects=true).

Kowalska, Natalia. 2018. “Oddawanie głosu: o prawach i proteście osób z niepełnosprawnościami" [Giving the voice back: about rights and protest of people with disabilities]. Pp. 79-94 in Niepetnosprawność $i$ społeczeństwo. Performatywna siła protestu [Disability and society. Performative power of protest], edited by E. Godlewska-Byliniak and J. Lipko-Konieczna. Warsaw: Fundacja Teatr $21 \&$ Biennale Warszawa.

Lewandowska, Monika. 2018. “Oczekuję z niecierpliwością na odpowiedź od Kai Godek” [I am waiting impatiently for an answer from Kaja Godek]. Gazeta Wyborcza, March 26. Retrieved November 9, 2018 (http://wyborcza.pl/7,95891,23192415,oczekuje-z-niecierpliwoscia-na-odpowiedz-od-kai-godek.html).

Lipko-Konieczna, Justyna. 2018. “Niepełnosprawność w polu władzy. Zaproszenie do performowania" [Disability in the field of power. Invitation to performing]. Pp. 99-113 in Niepełnosprawność i społeczeństwo. Performatywna siła protestu [Disability and society. Performative power of protest], edited by E. Godlewska-Byliniak and J. Lipko-Konieczna. Warsaw: Fundacja Teatr 21 \& Biennale Warszawa. Mielczarek, Andrzej. 2010. Człowiek stary w domu pomocy społecznej: z perspektywy polityki społecznej i pracy socjalnej [An elderly person in a nursing home: the social policy and social work perspective]. Torun: Wydawnictwo Edukacyjne Akapit.

Mladenov, Teodor. 2017. "From State Socialist to Neoliberal Productivism: Disability Policy and Invalidation of Disabled People in the Postsocialist Region." Critical Sociology 43(7-8): 1109-1123.

Pikuła, Norbert. 2011. Etos starości w aspekcie społecznym: gerontologia dla pracowników socjalnych [The ethos of old age and its social aspect: gerontology for social 
workers]. Cracow: Wydawnictwo WAM.

Priestley, Mark. 2007. "In Search of European Disability Policy: Between National and Global.” Alter 1(1):61-74.

Próchniewicz, Dorota. 2015. “Asystent, czyli kto?” [Assistant, that is who?]. Niepełnosprawni website, March 15. Retrieved March 19, 2019 (http://www.niepelnosprawni.pl/ledge/x/251351).

Savage, Sally and Nicole Carvill. 2009. "The Relationship Between Undertaking an Informal Caring Role and Social Exclusion.” Pp. 87-95 in Theorising Social Exclusion, edited by A. Taket, B. R. Crisp, A. Nevill, G. Lamaro, M. Graham, and S. Barter-Godfrey. New York: Routledge.

Sekułowicz, Małgorzata. 1998. “Problematyka funkcjonowania rodzin dzieci niepełnosprawnych.” [Problems of Functioning of Families of Children with Disabilities] Teraźniejszość - Człowiek - Edukacja 10(1): 61-82.

Stacey, Clare. 2011. The Caring Self. The Work Experiences of Home Care Aides. Ithaca, NY and London: Cornell University Press.

Szatur-Jaworska, Barbara, Piotr Błędowski, and Małgorzata Dzięgielewska. 2006. Podstawy gerontologii społecznej [Basis of social gerontology]. Warsaw: Oficyna Wydawnicza Aspra-Jr.

Woźniak, Zbigniew. 2008. Niepełnosprawność i niepełnosprawni w polityce społecznej. Społeczny kontekst medycznego problemu [Disability and the disabled in social policy. Social context of the medical problem]. Warsaw: Wydawnictwo SWPS Academica.

Zięba-Kołodziej, Beata. 2014. „Różnorodność przeżyć, jednorodność cierpienia - o problemach opieki w warunkach domowych nad osobami starszymi” [Diversity of experiences, uniformity of suffering - about problems of home care for the elderly]. in Historyczno-społeczne aspekty starzenia się i starości: praca zbiorowa [Historical and social aspects of aging and old age: collective work], edited by M. Stawiak-Ososińska and A. Szplit. Kielce, Włocławek: Agencja Reklamowa TOP-Drukarnia Cyfrowa Format.

Zych, Adam A. 2010. Leksykon gerontologii, hasło: dom pomocy społecznej [A lexicon of gerontology, entry: nursing home]. Cracow: Oficyna Wydawnicza Impuls.

Żebrowski, Paweł. 2019. "RPO apeluje o stworzenie programu wsparcia dla opiekunów osób niepełnosprawnych” [Ombudsman's call to create support program for caregivers of disabled people]. Prawo.pl, February 28. Retrieved October 1, 2019 (https://www.prawo.pl/kadry/potrzebny-program-wsparcia-dla-opiekunow-osob-starszych-i,377850.html). 


\section{BIOGRAPHICAL NOTE}

Michalina Grzelka is a linguist and an anthropologist, she is an instructor and a doctoral candidate at State University of New York at Albany in the United States, Department of Anthropology.

Katarzyna Szostakowska is a trained social worker, specializing in services for elderly and an assistant professor at the Social Pedagogy Department, at the Maria Grzegorzewska University in Poland.

OPEN ACCESS: This article is distributed under the terms of the Creative Commons Attribution Non-commercial License (CC BY-NC 4.0) which permits any non-commercial use, and reproduction in any medium, provided the original author(s) and source are credited.

ARTICLE HISTORY: Received 2019-09-30/ Accepted 2019-11-20 
